Paedagogia Christiana

2/46 (2020) - ISSN 1505-6872

DOI: http://dx.doi.org/10.12775/PCh.2020.024

Monika Sztamborska*

ORCID: 0000-0003-4571-5176

Pniewy, Polska

\title{
The Education of Children and Youth to Service According to the Pedagogical Approach of Saint Ursula Ledóchowska
}

\author{
Wychowanie dzieci i młodzieży \\ do służby w koncepcji pedagogicznej \\ świętej Urszuli Ledóchowskiej
}

\begin{abstract}
This article deals with the system of education established by Saint Ursula Ledóchowska (1865-1939), the founder of the Congregation of the Ursuline Sisters of the Agonising Heart of Jesus, the major mission of which is educating and teaching children and youth. The intention is to present one aspect of her pedagogical thoughts - the education of children and youth to service - which is understood as shaping attitudes such as goodness or dedication, overcoming selfishness, sharing time and talents, as well as ensuring the acceptance of good received from others and shaping the attitude of gratefulness. The text consists of four parts. The first part shows the understanding of service according to Ursula Ledóchowska. Next, her childhood is presented as inspiration for her further life and her educational care work. The third part deals with the concepts of educating children and youth to service, starting with the most common and accessible forms before examining those that are more difficult and require some greater involvement. The final section

* S. mgr Monika Sztamborska USJK, Liceum Ogólnokształcące Sióstr Urszulanek SJK im. św. Urszuli Ledóchowskiej w Pniewach, Poland; email: sztamborska.monika@outlook.com.
\end{abstract}


demonstrates that, according to Saint Ursula Ledóchowska, the source of service is the experience of God's love and the willingness to share it while doing good.

Keywords: Ursula Ledóchowska; the Congregation of the Ursuline Sisters of the Agonising Heart of Jesus; service; volunteering; Christian education.

Abstrakt: Przedmiotem refleksji jest system wychowania św. Urszuli Ledóchowskiej (1865-1939), założycielki Zgromadzenia Sióstr Urszulanek Serca Jezusa Konającego, którego główną misją jest wychowywanie i nauczanie dzieci i młodzieży. Celem artykułu jest ukazanie jednego z aspektów jej myśli wychowawczej, jakim jest wychowanie dzieci i młodzieży do służby rozumianej jako kształtowanie postaw dobroci, ofiarności, opanowywania egoizmu, dzielenia się swoim czasem i talentami, a także uwrażliwiania na przyjmowanie dobra od innych i kształtowania w sobie postawy wdzięczności. Tekst składa się z czterech części. Pierwsza prezentuje pojęcie służby w rozumieniu Urszuli Ledóchowskiej, kolejna opisuje jej dzieciństwo jako inspirację do dalszego życia i działalności opiekuńczo-wychowawczej. Trzecia część ukazuje koncepcje wychowania dzieci i młodzieży do służby od najprostszych i najbardziej dostępnych form po coraz trudniejsze i wymagające coraz większego zaangażowania. Ostatnia część ukazuje, że źródłem służby wg św. Urszuli Ledóchowskiej jest doświadczenie miłości Boga i chęć dzielenia się nią poprzez czynienie dobra.

Słowa kluczowe: Urszula Ledóchowska; Zgromadzenie Sióstr Urszulanek Serca Jezusa Konającego; służba; wolontariat; wychowanie chrześcijańskie.

\section{Introduction}

If I had more time,

I would do more, what to do!

Ursula Ledóchowska

Saint Ursula ${ }^{1}$ Ledóchowska (1865-1939) is the founder of the Congregation of the Ursuline Sisters of the Agonising Heart of Jesus whose specif-

${ }^{1}$ Ursula is a religious name that Julia Ledóchowska took at the beginning of her novitiate on April 17, 1887 in the Ursuline convent in Cracow. In this text, the name Julia refers to the time before she entered the convent. In 1897, ten years after her vestition, she obtained 
ic mission is the proclamation of Christ - the love of His Heart - through educating and teaching children and youth as well as serving the neediest in society (USJK, 2016, p. 14). From 1920 to 1939 she established 36 communities in Poland, five in Italy and three in France (Raułuszkiewicz, 1981, pp. 33-34). At the time of her death there were 777 sisters in the Congregation working throughout the various educational care centres, nursery schools, halls of residence, schools, and common rooms (ibidem, p. 241). While there is a wealth of literature on her life and activity, little research has been undertaken on her pedagogical thoughts. The publication entitled Zarys systemu wychowania Urszuli Ledóchowskiej (2002), prepared by Katarzyna Olbrycht, seems to be single extant example. In 2020, it was extended and published in a third edition entitled Pedagogia św. Urszuli Ledóchowskiej. The book describes the pedagogical activity covering the spiritual, mental and physical spheres of the pupils' lives, which are developed through moral-religious, intellectual, socio-patriotic, aesthetical, and physical education.

All of Ledóchowska's educational activities were aimed at the integral education of children and youth. The care for salvation of every met person was the bond of her actions. The educational system she implemented in numerous educational institutions and children's organisations lacks a theoretical foundation; however, Saint Ursula left a wide range of materials, including memories of her pupils who appreciated her 'apostolate of smile' and her desire to create good educational atmosphere. It is worth seeing the deep sense of this pedagogy.

The aim of this article is to present one aspect of her pedagogical thoughts - the education of children and youth to service - which is understood as shaping the attitudes such as goodness or dedication, overcoming selfishness, sharing time and talents, as well as making her students aware of the acceptance of good received from others and shaping the attitude of gratefulness. The text consists of four sections, the first of which is the understanding of the notion of service according to Ursula Ledóchowska. Next, her childhood is presented as an inspiration for her life and her educational care work. The third part deals with the concepts of educating children and youth to service beginning with the most common and accessible forms before exploring those which are more difficult and require greater involvement. The final section demonstrates that, according to Saint Ursula Ledóchowska, the

the title of 'Mother' according to the Ursuline tradition. From that moment, both the sisters and children often referred to her tenderly as 'Matuchna' (in Polish: diminutively 'Mother'). 
source of service is the experience of God's love and the willingness to share it while doing good.

The following resources have been essential in the preparation of this article. The first of these is the memories of a younger sister Franciszka Ledóchowska, which are part of a wider study entitled Wspomnienia o Matce Urszuli Ledóchowskiej osób spoza Zgromadzenia. The speeches of Saint Ursula to the youth and the articles she was writing to the alumnae of the school in Pniewy, published in a magazine entitled Dzwonek św. Olafa, have also been utilised. Moreover, there is a wide range of correspondence that includes numerous educational guidelines addressed to the sisters, educators, and former alumnae.

\section{Service according to Saint Ursula Ledóchowska}

O Jesus, my King,

I want to love you in my neighbours,

for you I want to serve them,

as it is the only way to show you

my love in deed.

Ursula Ledóchowska

The term 'service' has multiple, often contradictory, meanings. One of them is the understanding of service as slavery with no right to freedom that shall be provided to every fully-fledged member of society. Alternatively, it refers to the pursuit of honours and privileges of service that arise from the attitude towards the ruler, nation, or any cultic ministry within a certain religion. Over the centuries there has been a huge variety of interpretations regarding this concept. In this article, the author refers to the Encyclopedia of Pedagogical Axiology:

... the category service refers to any action that is undertaken for a certain concept, dedication to some matter ('give oneself for the service of' a homeland, nation, society, to undertake tasks for the good of others). The aim of such activities is not maximisation of profit but implementing community beneficial actions. In this context service can also be seen as volunteering or the functioning of the non-profit organisations. (Jańczuk, 2016, p. 1073) 
According to the concept of Saint Ursula explored in this article, a sense of service does not have any features typical of slavery (which opposes and represses human dignity); furthermore, it does not involve profiting from honourable titles and functions or obtaining any material benefits.

The basic distinction between the various concepts of 'service' has a biblical foundation. There are two terms that describe 'a servant' in the New Testament: the first is doulos, which means a servant-slave or a servant-subject, and the second, diakonos, refers to a servant-helper (Popowski, p. 128, 144). In reference to the second term one may speak about the work for the neighbour, e.g. through the works of mercy (see Mt 25:31-46). Such an understanding of service enhances the subjectivity within the relationship between both sides. Therefore, the notion of service is characterised by 'the personalistic tendency' (Dylus, p. 534-536).

When writing about service, Saint Ursula was thinking of the latter concept; she considered service to be love towards God, serving Him in every needy person and above all in children and youth. Indeed, in her meditations to the Gospel she referred to the sisters with the following words: 'God gives us this grace that He calls us to His service. To serve God - means to reign; to serve God - it is the greatest happiness that we have on earth' (U. Ledóchowska, 2000c, p. 218-219).

St Ursula never treated service as a form of enslavement; rather, she perceived it as the source of dignity and happiness. In numerous writings dedicated to the sisters she encouraged them to practice ardent service to others:

Does Jesus confirm His divine mission in words? No. He wants his deeds to give His testimony, which contains a profound teaching. We need to show others that we belong to Christ, that we are His. That testimony shall not be given in beautiful words or a cliché but in deeds. So that we may be able to say that the proofs of our love for Christ the Lord are our goodness to others, dedication to neighbours, willingness to serve; that our love is neither in the words, even the most beautiful, nor in feelings but in deeds. (U. Ledóchowska, 2000c, p. 146)

Saint Ursula presented the aim of service as an expression of love towards God in deeds rather than words, which may turn out to be merely empty declarations. She knew that the commitment to serve others is exhausting and that is why she valued the friendly atmosphere, mutual support and rest time within the communities formed by the sisters. Forced to act in conspiracy during her stay in St Petersburg, Saint Ursula adjusted the religious 
life demands to the needs of her sisters. ${ }^{2}$ While implementing a generous service-oriented attitude among the sisters, she wanted them to act according to their capabilities (U. Ledóchowska, 2000c, p. 497-498). In her letters she often referred to the sisters tenderly and attentively, asking them about their health and the conditions in which they were living. She also highlighted her concern about the constant overwork of the sisters. There was no gullibility in her attitude of service; for instance, on one occasion she decided to transfer a pupil to an alternative location because the boy caused many problems, had bad influence on the younger children, and did not want to change his behaviour (U. Ledóchowska, 1999, p. 107).

Ursula Ledóchowska undertook such actions to demonstrate the value and the beauty of service not only to the sisters but also to the teachers, wives, mothers, youth and children that she was raising or for whom she was writing numerous articles and books. Indeed, during a speech delivered at a teaching course on September 21, 1926 she outlined the following educational objectives:

We have a twofold task in the field of education. Firstly, it is to educate children towards God, towards the heavenly homeland. Secondly, it is to educate children towards society, towards the earthly homeland. Therefore, our motto in education is: for God and the homeland. (U. Ledóchowska, 2005, p. 57)

Katarzyna Olbrycht interpreted the above words and described the pedagogy of the Saint as follows:

When analysing Mother's statements and efforts, her intentions can be clarified. The most important is to lead children to the loving God. They should be taught that the surest way is the intimacy with Jesus Christ in the Blessed Sacrament as

2 'My little sister, I have a problem - what do you think about this? Everyone feels happy here. We live calmly and quietly, following the habits of the Cracovian convent. Yet, there is something that we do not manage to fulfil. I believe I can change it without blame. The sisters in Cracow have their recreation after dinner and supper. Here, it is impossible due to the lack of time. If there is silence, the sisters will have no possibility to talk about themselves and their matters. One lives away from the other, whereas in our depressive climatic conditions everyone feels the need for closeness and mutual love that will strengthen us. Therefore, although there is reading at dinner, I ring the bell by the end of meal and allow people to talk for about 10-15 min. Also, there is half an hour of recreation during teatime and supper. I feel that this is necessary as it reinforces the spirit and deepens unity.' (U. Ledóchowska, 2007, p. 21) 
well as trustful recourse to the help of the Mother of God. The second objective, following from the first, is to 'educate towards the society'. It is, according to Saint Ursula Ledóchowska, the preparation for the pupils' constructive contribution to social life. That results in reliability and responsibility at work as well as in active reactions to social demands, especially of the neediest, whereas the education 'towards the earthly homeland' means to elicit and teach the oblative love of Poland. (2012, p. 549)

The direct aim of education is to encourage children and youth to recognise God's love and to have a personal relationship with Him. This is the proper way to understand the value of service, which Saint Ursula understood to include a wider perspective whereby service is dedicated to the state. During World War I, Ursula Ledóchowska delivered a number of speeches on Polish history and culture while staying in the Scandinavian countries in order to raise awareness regarding the captive homeland as well as to collect funds for the General Committee for the Relief of the Victims of War in Poland. During one of the lectures she encouraged mutual cooperation within society:

We are all - we, the inhabitants of earth - children of one Father, our Father, who is in heaven, so we need to help one another. Those, who have got the light of God, should guide the ones in the darkness. Those, who have got the knowledge, should give it to the ones who seek for the teaching of Christ. Those, who possess property, should support the most precious particle of Christ's Church the poor, the widows, the orphans, the sick. Those, with hearts open to human misery, should bring words of comfort to the miserable: weep with those who weep and rejoice with those who rejoice. (U. Ledóchowska, 2018, p. 69)

Her ideal of life was to see people who support and serve one another through knowledge, talents, material assistance or supportive words. She sought deep interpersonal relationships and wanted every citizen to feel included within the society and contribute to its development. This is why she encouraged parents and educators to work for the country by engaging them in fully aware upbringing. Furthermore, she believed the youth would be capable of helping through their voluntary work whereas the sisters would serve anyone in need. 


\title{
3. Saint Ursula's family home as a place shaping the attitude of service
}

\author{
In relation to her siblings \\ she was the most sensitive, loving sister, \\ always ready to do any favour, \\ despite the cost \\ of her own comfort and pleasure.
}

Francesca Ledóchowska

Saint Ursula's generous attitude, lack of selfishness, and cheerful dedication to others were clearly virtues taken from her family home. Born in 1865, she was the second of nine children born to Josephine and Anthony Ledóchowski. She also had three half-brothers from her father's ${ }^{3}$ previous marriage, so care for her younger siblings was not unfamiliar and meant she often had to give up her own plans. Despite playing together, she was also taught her younger siblings. Her selflessness in early life is also evidenced by helping Mary Theresa in her migraine attacks and taking care of her when she suffered from pox at the age of 22. In addition, she supported her wistful and depressive father. Saint Ursula's generous heart is described by her younger sister Francesca as follows: 'The young Julia was often giving up her pleasures for the benefit of others. Also, she desired to devote herself to others. She was like a second mommy, making various surprises on Saint Nicholas Day as well as on other occasions' (F. Ledóchowska, 2004b, p. 114). A further example of her older sister's goodness is provided in Francesca's memoirs: 'Her behaviour was simple, natural. We were all used to her constant goodness and that everyone asked her for any favours. Full of life, initiative, enthusiasm - she stood out from her siblings with her generosity and dedication' (F. Ledóchowska, 2004a, p. 99).

As a child, Julia cared a lot about her appearance and she liked wearing beautiful dresses and ribbons. With age, however, she ceased to be interested

${ }^{3}$ After the death of his first wife Maria von Seilern, Anthony Ledóchowski was left with three sons: Timothy (1855-1885), Anthony (1856-1935), and Casimir (1857-1930). On June 17, 1862 he married Joesphine Salis-Zizers. Josephine and Anthony had nine children: Mary Theresa (1863-1922), Julia (1865-1939), Vladimir (1866-1942), Mary (1867-1879), Ernestine (1869-1950), Francesca (1870-1953), Ignatius (1871-1945), Josefa (1872), and Stanislav (1878). 
in 'vain' primping. After moving to Lipnica Murowana ${ }^{4}$ she spent her own pocket money on the education of two boys: Peter Żaczek and Pietraszkiewicz $^{5}$ (ibidem, p. 102). After her father's death she allowed Francesca and Ernestine to choose the black hats with veils first, whereas she took the smallest and the least matching for herself (F. Ledóchowska, 2004b, p. 120).

Julia's generosity reflected her parents, who cared about the upbringing of their children in mutual harmony and respect to every person. They raised their offspring in openness to the needy; for example, the children were instructed to take various gifts to the poor or to the nearby deaf and dumb institute (F. Ledóchowska, 2004a, p. 101). Julia followed her mother's footsteps by taking care of the sick people from Lipnica and its surrounding areas using home remedies:

Her apostolate of love was not provided only within the framework of her own family - she was able to find the needy with ease. She was visiting the sick and poor in their houses or she accepted them in the manor, despite the complaint of her old servant Ferdinand who was grumbling that 'the count's daughter brings rabble to the manor' and he was the one to clean everything. Moreover, with the help of her siblings, she was organising a Christmas tree as well as the First Holy Communion celebration for the local children. She was always truly selfless in her deeds towards others and she did not expect any gratitude (F. Ledóchowska, 2004b, p. 119).

Many of those in need were looking for help from the Ledóchowski manor house at the time of the county fair. Following her mother, Julia took care of a disabled woman who lived nearby and had two sons; indeed, she began tutoring and feeding one of them in the manor. The news about Julia spread rapidly throughout the countryside. The astonishing fact is that Julia was very young - just 18 years old - when she moved from Austria into the formerly Polish territory. After her father's death, she helped her mother (who did not understand Polish) with running the farm and this involved a huge amount of responsibility, time and effort. The custom of a Christmas tree for the poor children at Lipnica manor was introduced on her initiative. The children were always invited on Boxing day and given dainties. A similar initiative was the First Holy Communion for the children of Lipnica, who

${ }^{4}$ From 1883 to 1886 Julia lived in Lipnica Murowana near Cracow, which was her father's homeland.

${ }^{5}$ The resource lacks the first name of Pietraszkiewicz. 
were invited for a solemn breakfast. These customs were also practiced later in life when Julia entered the convent (F. Ledóchowska, 2004a, p. 102-103).

The attitude of service towards God, the homeland and other people realised by Saint Ursula was inspired by the her parents' generosity. Moreover, her childhood had an impact on the creation of her educational concept, which aimed at bringing everyone to God. This was achieved by showing others the love of Christ and the fruit of this experience was the service towards others through goodness, generosity, help, unselfishness and smiling.

\title{
4. Shaping the attitude of service among children and youth in the educational approach of Saint Ursula
}

\author{
I always tell children \\ that this year or two they spend with us \\ is preparation for life.
}

Ursula Ledóchowska

Saint Ursula, as a teacher and educator, took care of the integral development of her pupils. She taught them how to develop their passions and abilities, warning against 'vain' ambition and at the same time showing how to use them not only for the good of their relatives but also for society and the homeland. In particular, she encouraged sensitivity to the needs of the local environment through the arrangement of various actions on behalf of the children and the elderly. Above all, she wanted her students to make others happy on a daily basis through the discreet propagation of good.

\subsection{Serve with goodness and a smile}

\author{
In showing goodness, \\ we shall start from the smallest things \\ and we shall not stop our dedication. \\ The whole beauty and nobility of \\ goodness is in dedication.
}

Ursula Ledóchowska

Simplicity characterised Saint Ursula Ledóchowska and that is why her numerous methods are marked by this virtue. Simultaneously, they formed 
deep and sustainable values. She encouraged others to be good to everyone regardless of their affection or differences in worldview. Consequently, she prepared children to abandon their selfish attitude and to lay the foundations for the attitude of service.

During December 1920, during a retreat for pupils in Pniewy, she focused intently on the concept of goodness:

Goodness elates the world, which needs warmth, goodness, comfort, support and alleviation. Goodness converts the souls and makes good those we deal with on a daily basis. The bad are often those who have not received any goodness in their lives yet. All the good will vanish if it is not surrounded by goodness. Goodness is the enormous apostolic and educational strength. Our view of the world often depends on it. If we experience goodness, we slowly change ourselves and see the world differently. It happens very often that a man who is a pessimist - discouraged, bitter, suspicious, and mocking everything - has not experienced goodness in his life. Our view of the world depends on the amount of the goodness we receive. (U. Ledóchowska, 2004c, p.14)

Due to her practical nature, she did not merely use exalted words; rather she provided practical indications regarding how to do good while serving others in everyday life. Indeed, she explained to her pupils that goodness can neither be intrusive nor restrict the freedom of others. It should be selfless and the only motive for doing good should be following Jesus Christ. As an educator, she was encouraging her listeners to be good to everyone and not only to those who were kind to them. Here, she warned against ambition and 'vanity' and this is why she encouraged the discreet propagation of good. The youth were asked to examine their thoughts as not only are they the source of goodness, serenity, and consideration but also judgement, slander, and jealousy. She had words of comfort, encouragement, and kindness towards everyone as she knew their value:

Good words are born from good thoughts. Good words come from the purified source of thoughts. The strength and power of a good word is enormous and it may bring relief from suffering, lift up from a fall and give courage. A good word is only harmless praise - it is like a medicine without poison. A good word can do more than deeds; we have more occasions for it and it does not require thankfulness, which some people are afraid of, as it entails deeds. (ibidem, p. 15) 
Next, she taught the youth that good thoughts and words facilitate the way to good deeds. The young people educated by Saint Ursula were sensitised to the social needs of the local environment through the arrangement of various actions on behalf of the children and the elderly. In her memories, she described the reaction of one of her pupils after the arrangement of a fundraising performance and ball for a certain orphanage:

On the way back one of the Norwegian pupils, a kind-hearted girl, told me: 'I had no idea that it is so pleasant to do something good for others!'. Poor children, they have never been taught what seems to accurately define the German proverb: 'Geben ist seliger dennnehmen. ${ }^{6}$ ' One of the surest sources of happiness was closed to them. (U. Ledóchowska, 2006, p. 148)

She claimed that goodness is the source of happiness. When we give of ourselves and share our talents, we in turn benefit. Her teaching espoused that the easiest form of goodness is bestowing a smile on others, and as a result Saint Ursula is often called the apostle of smile. In her Congregation she forbade exhausting fasts and penances; instead, she taught her sisters that penance is constant cheerfulness. Although this approach to life may appear straightforward, it becomes challenging when you feel unwell and in pain or if you are tired or exhausted; in these circumstances, fortitude is essential in order not to focus on yourself but bring joy to others. A cheerful face shortens the distance, encourages us to make contact, and makes others feel better.

O you, young, go into the world with a smile on your face, spread some happiness in this valley of tears. Smile to everyone but especially to those who are sad, underwhelmed by life, falling under the burden of the Cross. Smile towards them with this bright smile, which always shows the goodness of God; remind them that although the dark clouds have gathered, whenever you lift your eyes up you may feel this marvellous, though small, sliver of blueness. This bright, divine happiness shall send a small gleam of eternity that heals wounds, reduces sadness, brightens the present life with hope, and lifts us up to God. (U. Ledóchowska, 2000a, p. 98)

Smiling is available to everyone. Each person can carry hope to others through a smile. A cheerful face shows to those who are discouraged and sad

\footnotetext{
6 Translation from German: it is better to give than to take.
} 
that not all is lost and that better times will come. The pedagogy of the smile is far more than only shallow 'smiley-ness'. Saint Ursula wanted to show the deeper sense of this pedagogy while creating an educational atmosphere based on safety and trust, which is the basic condition of the proper psychophysical development of a young person.

\title{
4.2. Serve with time and talent
}

\author{
Try to go through life \\ bringing happiness \\ to your neighbours.
}

Ursula Ledóchowska

In the interwar period Ursula Ledóchowska came up with her next initiative, which nowadays could be called the idea of volunteer work. Through numerous articles and radio broadcasts, she encouraged girls to take part in social work. Firstly, the volunteers gained some experience from the sisters in well-developed educational establishments. Next, those who were still interested moved to the most neglected places in Polesie, ${ }^{7}$ where they served the locals alongside the Ursulines. Saint Ursula emphasised that she did not seek any vocations to the religious life through this work; rather, she encouraged temporary work whereby the volunteer would gain experience useful in later life. On this occasion, she appealed to young Poles. This appeal was published in Dzwonek św. Olafa as well as in many other Catholic magazines and via radio broadcasts:

My children, we do too little. From everywhere I receive pleading letters and requests to take over the establishments in the borderlands: Catholicism is under threat, the morality is vanishing, the heresy is triumphing, they are crying

${ }^{7}$ Polesie is a geographical and historical region, located mainly on the territory of Belarus and Ukraine, yet it also encompasses some parts of Poland and Russia. Polesie is a flatland, situated in the valleys of Pripyat and Bug rivers, approximately 100-200 metres above sea level (the maximum height is 316 metres). It is located on the south-west part of the East European Plain. From the end of World War I until 1939 the western part of Polesie with Brest-on-theBug, Pinsk, and Luninets belonged to Poland whereas the eastern part was a region of Soviet Russia. At that time Polesie was the most backward region of the country. The rate of illiteracy was the highest in Poland. The majority of citizens could not identify their national affiliation (they called themselves 'locals') and they mostly spoke Belarusian or Ukrainian subdialects. 
out for help and I have to harshly respond 'no!' because there is no one to work there. My children, I do not encourage you to religious life - as God is the One who gives vocation. I am rather asking: could you devote two to three years of your youth to God and our homeland? Maybe your brother serves in the army after all, every young man is obliged to do a few years of military service and it does not interfere neither with career nor with marriage when the time comes for it. Why wouldn't you devote a few years of your life to serve your country? Do you want to get married? It will not flee and a few years of social work is the best preparation for marriage. Whenever I ask a young girl who does not need to work, 'What do you actually do?,' I always receive answers such as: 'I attend lectures on history, history of fine art and literature as an auditor. I go to the conservatoire, I attend social work courses, etc., and two or three times a week we sew for the poor or organise games for girls working in factories.' These are all really beautiful activities and at the same time you are looking for a husband and that is also a very laudable activity. But what do you actually do for your country or for our Holy Church which is threatened? I will tell you my child: military exercises are a very good thing in times of peace; but does a soldier who practises military exercises and does not go to war deserve praise or rather dishonour? Nowadays, it is not the time to learn about social work on courses - it is the time for social work for God and your homeland. A few years ago a considerable number of young girls eagerly attended numerous courses on social work: how to run closed establishments, how to educate children there, etc. Was there at least one who went on to work in such closed establishments? No way! They have probably already forgotten even the theory. But they are really proud that they did some social work. Of course, these courses cost a lot, so what? I can teach you social work with no courses, no theory, as there is no time for it, but in practice. If there are at least a few eager to work, we can take care of some establishments. I am not asking for myself but for the souls over there - for the borderlands and villages where the heresy is spreading, for families in which immorality kills love and virtue, and for children who are not being told about the Child of God, who stretches out His hands to them, or about the rainbow wings that the Guardian Angel uses to protect them against the evil... not for myself I cry out but rather for them to you, my alumnae of St Olaf, to you who neither have to earn your daily bread nor have to prepare for gainful employment through serious work, to you who haven't established your own homes yet, to you who are waiting. Contact us - there are so many establishments waiting and we can save so many souls and contribute to spreading the Kingdom of Heaven in our country! It is not enough to pray: 'Thy Kingdom come' - we need to work so that the Kingdom of Heaven can actually come. 
Therefore let's work, at least a few of you, my dear alumnae of St Olaf! Let's save people! $!^{8}$ (U. Ledóchowska, 1927, p. 10)

There is a reason in citing almost all of the foregoing appeal of Ursula Ledóchowska as it contains the core of her approach to educating the youth to serve the society and the country. It was primarily targeted at the alumnae of the St Olaf school in Pniewy, ${ }^{9}$ whom she taught to spread joy and cheerfulness. She also encouraged them to become engaged in various charity actions, e.g. collections for poor children or sewing clothes for them. However, in the appeal to her alumnae, she stated that such actions are insufficient. It looks as if in her educational concept Saint Ursula was establishing different circles, from the broadest possible which was available to everyone at any age to the narrower version which would require increased generosity, time and a wider range of skills. Eventually, she reached the core idea - two or three years of service for the girls in Polesie in very harsh and primitive conditions. ${ }^{10}$ She wanted to inspire those girls who had graduated from school and who were staying at home, had a lot of spare time, and were waiting for a future husband. She often cautioned her alumnae against selfishness and materialism in a magazine entitled Dzwonek św. Olafa:

We live in the age of great inventions and they all aim at making the life of humans more comfortable and easier! We are completely engulfed in materialism - and as we are all more or less influenced by the environment in which we live, we are also more or less engulfed in materialism. I say more or less as it depends on our reactions. Yes, we need to guard ourselves and not let the earth

${ }^{8}$ The appeal of Saint Ursula, usually entitled Ratujcie Kresy!, was published in many magazines, e.g. Przewodnik Katolicki, Kurier Warszawski, and Dzwonkek św. Olafa, as well as on various radio broadcasts.

${ }^{9}$ Ursula Ledóchowska named the first property bought on the Polish territory The plant of St Olaf. Choosing St Olaf - the patron saint of Norway as the patron saint of the house in Pniewy was a token of gratitude towards the Norwegian consul in Denmark, who offered 20,000 crowns for the purchase. Due to the name The plant of St Olaf, the pupils at the school in Pniewy were known as the pupils of St Olaf.

${ }^{10}$ The first person who responded to the appeal of Ursula Ledóchowska was Janina Kalinowska (1902-1987). When corresponding with her, Saint Ursula was making her aware of the difficulties of such work and the great generosity that would be essential: 'Are you able to give up your gratification or do you need it? We cannot pay much, as the borderlands are poor. Do you understand that one has to go to such work as on a mission - with great dedication and readiness for fatigue and hardship? (U. Ledóchowska, 2000b, p. 157). 
absorb us; we need to remind ourselves again and again that we were not created for earth and that our life should be consumed in the work for God, in this confidence that we live for God and not for our miserable 'self.' (U. Ledóchowska, 2000a, p. 46)

This utterance from 1930, in which she describes the world as the time of selfishness, is still valid today. She severely criticised concentrating only on the material aspect of life. Through the example of life, she presented service as a path to happiness for both the bestowed and the giver. Saint Ursula was a person of high intelligence; she understood many languages, had a great variety of talents, and at the same time was able to serve others regardless of their religion or social status.

Her sisters and pupils remember her as a person able to share love, joy and time, e.g. during apostolic activities, conversations and correspondence. While sharing her skills, she was encouraging others to generously give themselves on behalf of the development of society as a whole.

\title{
4.3 Those who serve gain
}

\author{
I pray for You, \\ my Sister, \\ and I will always keep \\ the feeling of gratitude towards you.
}

Ursula Ledóchowska

While educating children and youth to various forms of service towards God, homeland and the other people, Ursula Ledóchowska also highlighted the crucial motives of such activities. Doing everything with the intention to God was fundamental. Simultaneously, she claimed that the aim of service extends beyond goodness, which stems from the action towards the bestowed person but also towards the giving person: 'My child, you will mature at this work, your spirit will grow strong; you will see the change in yourself because you were created for something bigger, more useful than just being the pride (often questionable) of salons' (U. Ledóchowska, 1927, p. 10).

These words demonstrated the overriding aim of her educational process, ranging from the easiest and most accessible forms to those that were more demanding in terms of hardship and engagement. Its core was to shape a mature woman who would be responsible for herself and for others as well 
as for her duties, distinguished by such features as responsibility, diligence, and systematicity. She also taught her students how to find self-esteem when serving others as well as how to discover the positive experience of feeling useful. This approach was especially common in the Scandinavian countries where she worked among girls from richer families, who were concentrated only on their appearance and spending time on games and other forms of entertainment.

In her service education, Ledóchowska focused on awareness regarding the goodness her students could receive via their surroundings. In this way, she warned against the temptation of full-sufficiency and independence while also highlighting the harmony between giving and bestowing and the attitude of gratefulness. She herself owed a lot to her parents and siblings. Evidence for this can be found in letters to her sister Mary Theresa and her brother Vladimir, where she thanks them many times for their compassion and help: 'Thank you, my beloved Sister, your goodness affects me and moves me to tears... I don't know how I can thank my beloved Sister for everything, and especially for the love I receive from you and which is so charitable' (U. Ledóchowska, 2007, p. 27).

As an educator, she knew that the best educational method is one's own example and this is why she often thanked her pupils, teaching them the attitude of gratefulness: 'Furthermore, I want to thank you dear children for what you have been to us. Thank you for your goodwill demonstrated towards us, for the effort to make progress in your study, for your joy, which was a ray of sunshine in our lives' (U. Ledóchowska, 2004b, p. 4). This quote originates from a speech at the end of the school year at the Institute of Languages in Stockholm (Sweden). It is also worth noting the words of gratitude towards the young women who responded to the appeal for service in the borderlands: ${ }^{11}$

May God bless You, my brave Children, brave Sisters of the 'Blue Cross' for your dedication. I am delighted because of you, my Children, as it is a delight to find so much sacrifice and dedication among the secular youth. As soon as it gets warmer, I will come to You, dear Children, because I want to hug you and thank so much. (U. Ledóchowska, 2000b, p. 283)

11 The girls who responded to the appeal concerned with service in the Eastern Borderlands were called the Sisters of the Blue Cross, although this was not an official organisation and the girls were volunteers on a relatively short-term basis. 
Shaping the attitude of gratefulness and accepting various services from others is equally as important in the pedagogical concept of Saint Ursula as sensitisation to doing good for others: 'Remember two things: that goodness is the ability to warmly thank, even for the smallest thing, and that goodness is the ability to accept service - even unnecessary service - warmly and with thanks' (U. Ledóchowska, 2000d, p. 18). According to Saint Ursula, the art of receiving is as important as the art of giving. Therefore, she emphasised the acceptance of the help and service provided by others to encourage good intentions and support their sensitivity and readiness to take initiative to make others happy. However, she warned against blatancy: 'Our goodness cannot overwhelm others. We also need to let others be good and must not concentrate only on ourselves' (U. Ledóchowska, 2000d, p. 15). Her teaching focused on the dignity of every person being bestowed with good and the importance of acting unobtrusively, without imposing the word 'me.'

Through the example of her own life, Saint Ursula demonstrated that giving is not a form of forgetting about yourself. She indicated that when we give, we receive much more, e.g. the increase in our self-esteem and empathy. The ensuring maturity also allows us to take responsibility not only for our lives but also those of others.

\section{The encounter and following Christ - the source and summit of service}

The permanent presence of the Most Blessed Sacrament

- I cannot imagine educational work without this internal centre of spiritual life.

Ursula Ledóchowska

Ursula Ledóchowska taught that every person was created to have a happy life in God's love and this is why she wanted a chapel with the Blessed Sacrament in every establishment she founded. Thus, she encouraged everyone to have a personal relationship with God, to discover His love and goodness, and to share it with others. She taught that prayer is, among other things, the key aspect of the struggle with our selfishness and, above all, it is the school of accepting God's love and learning how to love the way He does:

God does not expect anything unusual from us... only to understand that we belong to Him, for Him created, for the happiness in His love and that ev- 
erything, each of the indifferent activities in our everyday life, can turn into an act of God's love through these magic words: 'Jesus, everything for you.' (U. Ledóchowska, 2000a, p. 108)

The attitude of service to which Saint Ursula raised was supposed to have its source in the relationship with God. The experience of His love enables people to share everything that they receive from the Creator. She encouraged people to place God in the centre of their lives and to do everything with the intention for Him:

Improve our everyday matters - work more accurately, with greater punctuality, love, purer intention - this is what we need! Let us put all our effort into it and always remember that we are not sanctified by what we do but how we do it. This is why it does not matter what we do only if we do it - even the smallest and the most indifferent thing - with all the goodwill, God's love and forgetting about ourselves. (U. Ledóchowska, 2004a, p. 111)

Thus, her intention was to shape a deep inner motivation of her pupils to serve in various forms. She also warned her teachers to avoid any form of constraint towards the youth:

Support their zeal, light the more intense love to God as the strongest and the most effective wake-up call. I am not surprised by the fact that it is not that easy with the older children; nowadays young people are exposed to very harmful impacts, so you must be glad of a student's pious disposition and should not force her to be part of the organisation if she doesn't want to because constraint never brings any good. (U. Ledóchowska, 2000b, 166)

The above words show that for Saint Ursula God's love was the source and summit of serving and that everything comes out of it and leads to it; as a result, she avoided rewarding children for their positive attitudes towards service. She was telling them about the spiritual reality and taught them to conduct an examination of conscience from the spread of good or the lack of it:

Love towards God, which entails the love towards people - this is what we need above all, my dear Children. This is why the major examination of conscience is my attitude towards others. Am I kind, warm-hearted and understanding to everyone? (Remember that even one exception proves that you do not have God's love to the neighbour.) Do I not criticise? Do I not slander? Do I not 
express my outrage towards others? Am I ready to dedicate myself to others? Am I attentive? Do I have a kind, warm-hearted attitude towards everyone? (U. Ledóchowska, 2004a, p. 96)

Throughout her life Saint Ursula strived for unity with Christ; consequently, the words of Jesus Take it and eat, this is my body during the Last Supper became her principal motto:

'Take it and eat.' (Mt 26:26) Eat my strength, it is yours, I want to serve you with it. Take and eat my abilities, my talents if I can be useful through them. Take and eat my heart so that love may warm and brighten your life. Take and eat my time, may it be at your disposal... I am yours, as Jesus - the Host - is mine. (U. Ledóchowska, 2000c, p. 47)

Saint Ursula led a life following the example of Jesus, who sacrificed Himself. Prayer, adoration of the Eucharistic Jesus, everyday examination of conscience, and living in the state of sanctifying grace are forms which were the foundation of her life and activities. However, while practicing them herself, Mother Ursula never imposed religious practices on her pupils. For her, the piety of young people was supposed to be an expression of a genuine relation with Christ which results in love towards others and the readiness to serve him.

\section{Conclusion}

The aim of this article was to present one key aspect of the pedagogical thoughts of Saint Ursula, i.e. the education of children and youth to service through smiling, goodness, readiness to serve others, and acceptance of good. In combination, the goal of this approach is to shape the attitude of gratefulness. In her pedagogical thought, Saint Ursula explained how to develop the above-mentioned dimensions in children and youth in a manner which could be hugely helpful for a contemporary teacher and will undoubtedly have an influence on the integral development of a young person.

Saint Ursula is often called the apostle of smile. However, rather than being the core aspects of her pedagogy, smiling and cheerfulness are best described as significant elements. The core is the education towards the attitude of service to God, other people, the homeland, and the local community. These days, we would say that these actions aim at shaping the attitude of 
empathy and altruism among young people. This direction may become an inspiration for educators as it clearly specifies the key element of Christian education, i.e. the attitude of service. It is vital to remember this when one chooses Saint Ursula Ledóchowska as a patron saint for any educational institution.

Translated by s. Karolina Knobloch USJK

\section{References}

Dylus, A. (1998). Służba. In A. Zuberbier (Ed.), Stownik teologiczny (pp. 534-536). Katowice: Księgarnia św. Jacka.

Jańczuk, L. (2016). Służba. In K. Chałas, A. Maj (Eds.), Encyklopedia Aksjologii Pedagogicznej (pp. 1070-1073). Radom: Polwen.

Ledóchowska, F. (2004a). Wspomnienie o Matce Urszuli Ledóchowskiej. In Wspomnienia o Matce Urszuli Ledóchowskiej osób spoza Zgromadzenia. Pniewy: Zgromadzenie Sióstr Urszulanek SJK.

Ledóchowska, F. (2004b). Zeznanie piśmienne w sprawie opinii świętości i cnót Służebnicy Bożej Matki Urszuli Ledóchowskiej, na wypadek niemożności złożenia zeznań przed Trybunałem Procesu. In Wspomnienia o Matce Urszuli Ledóchowskiej osób spoza Zgromadzenia. Pniewy: Zgromadzenie Sióstr Urszulanek SJK.

Ledóchowska, U. (1927). Ratujmy! Dzwonek św. Olafa, 1.

Ledóchowska, U. (1999). Listy. Vol. 5. Warszawa: Zgromadzenie Sióstr Urszulanek SJK.

Ledóchowska, U. (2000a). Dzwonek św. Olafa, Wypisy. Warszawa: Zgromadzenie Sióstr Urszulanek SJK.

Ledóchowska, U. (2000b). Listy. Vol. 6. Warszawa: Zgromadzenie Sióstr Urszulanek SJK.

Ledóchowska, U. (2000c). Rozmyślania dla sióstr urszulanek Serca Jezusa Konającego. Vol. 1-2. Pniewy: Zgromadzenie Sióstr Urszulanek SJK.

Ledóchowska, U. (2000d). Testament. Warszawa: Apostolicum.

Ledóchowska, U. (2004a). Listy do sióstr 1914-1922. Warszawa: Zgromadzenie Sióstr Urszulanek SJK.

Ledóchowska, U. (2004b). Przemówienie do młodzieży w Djursholmie. In Przemówienia i rekolekcje dla młodzieży. Pniewy: Zgromadzenie Sióstr Urszulanek SJK.

Ledóchowska, U. (2004c). Rekolekcje dla uczennic szkoły pniewskiej 4-7 grudnia 1920 r. In Przemówienia i rekolekcje dla młodzieży. Pniewy: Zgromadzenie Sióstr Urszulanek SJK. 
Ledóchowska, U. (2005). Kobieta - apostotka eucharystii. Częstochowa: Święty Pawel.

Ledóchowska, U. (2006). Byłam tylko pionkiem na szachownicy... Wspomnienia z lat 1886-1924. Częstochowa: Święty Paweł.

Ledóchowska, U. (2007). Listy 1907-1914. Warszawa: Zgromadzenie Sióstr Urszulanek SJK.

Ledóchowska, U. (2018). Jesteś nieśmiertelna Ojczyzno ukochana Polsko moja. Pniewy: Zgromadzenie Sióstr Urszulanek SJK.

Olbrycht, K. (2002). Zarys systemu wychowania Urszuli Ledóchowskiej. Pniewy: Apostolicum.

Olbrycht, K. (2012). Pedagogia szarych urszulanek (Zgromadzenia Urszulanek Serca Jezusa Konającego). In J. Kostkiewicz (ed.), Pedagogie katolickich zgromadzeń. Historia i wspótczesność, t. 1 (pp. 537-565). Kraków: Impuls.

Olbrycht, K. (2020). Pedagogia św. Urszuli Ledóchowskiej. Poznań: Święty Wojciech.

Popowski, R. (1995). Wielki slownik grecko-polski Nowego Testamentu. Wydanie z petna lokalizacja greckich hasel, kluczem polsko-greckim oraz indeksem form czasownikowych. Warszawa: Vocatio.

Raułuszkiewicz, Z. (Ed.) (1981). Zgromadzenie Sióstr Urszulanek Serca Jezusa Konajacego. Szkic historyczny - stan aktualny 1920-1980. Poznań: Pallottinum.

USJK (2016), Konstytucje Zgromadzenia Sióstr Urszulanek Serca Jezusa Konającego (2016). Warszawa: Zgromadzenie Sióstr Urszulanek SJK. 